\title{
Keberhasilan Pelaksanaan Inisiasi Menyusu Dini Di Rumah Bersalin Dan Balai Pengobatan Taman Sari Pekanbaru
}

\author{
The Successful Implementation of Early Suckling Initiation In Taman Sari Clinical \\ Centre Pekanbaru
}

\section{Novita Rany, Sri Desfita *}

* Staf Pengajar STIKes Hang Tuah Pekanbaru

\begin{abstract}
Abstrak
Salah satu upaya yang dapat dilakukan untuk meningkatkan cakupan ASI eksklusif adalah melalui Inisiasi Menyusu Dini (IMD). Ada beberapa faktor yang dapat mempengaruhi keberhasilan pelaksanaan IMD diantaranya, kurangnya informasi ibu tentang IMD, kurangnya dukungan dari keluarga dan kurangnya motivasi dari petugas kesehatan. Tujuan dari penelitian ini adalah untuk mengetahui keberhasilan pelaksanaan IMD di Rumah Bersalin dan Balai Pengobatan Taman Sari Pekanbaru Tahun 2010. Penelitian ini menggunakan metode kualitatif. Subjek penelitian adalah ibu nifas yang melahirkan secara normal dan telah melaksanakan IMD, salah satu anggota keluarga ibu dan bidan. Cara pengambilan data dilakukan dengan observasi dan wawancara mendalam. Variabel yang dianalisis adalah pengetahuan ibu, motivasi keluarga dan motivasi petugas terhadap keberhasilan pelaksanaan IMD di Rumah Bersalin dan Balai Pengobatan Taman Sari Pekanbaru Tahun 2010. Hasil penelitian diperoleh bahwa pelaksanaan IMD belum terlaksana dengan baik dan benar dan pelaksanaan IMD belum berhasil. pengetahuan ibu tentang IMD masih rendah sehingga ibu tidak termotivasi untuk melaksanakan IMD sampai berhasil. Kurangnya informasi tentang IMD yang diperoleh keluarga ibu menjadi dasar motivasi dari keluarga juga rendah sehingga tidak dapat meningkatkan percaya diri ibu saat melaksanakan IMD. Motivasi petugas masih rendah. Hal ini dapat dilihat dari petugas tidak pernah memberikan informasi tentang IMD kepada ibu dan pelaksanaan IMD hanya berlangsung 15 menit. Disarankan kepada bidan di Rumah Bersalin dan Balai Pengobatan Taman Sari Pekanbaru untuk dapat meningkatkan pengetahuan tentang IMD, memberikan informasi tentang IMD kepada pasien dan memasang poster-poster tentang IMD.
\end{abstract}

Kata Kunci : Pelaksanaan IMD, keberhasilan pelaksanaan IMD, pengetahuan ibu, motivasi keluarga, motivasi petugas.

\section{Abstract}

One of the effort to increase coverage of exclusive breastfeeding is by Early Suckling Initiation (ESI). There are various factors affecting the success of ESI implementation, such as the lack of information of the mother about ESI, the lack of family support, and the lack of motivation from health staff. This study aims to know the success of ESI implementation and factors associated with the success of ESI implementation such as mother's knowledge, family support and motivation from health staff toward the success of ESI implementation in Taman Sari Clinical Centre, Pekanbaru, 2010.

Design of the study is qualitative. Subjects are women delivering their babies normally, member of the family, and midwives. Data were collected by observation and in-depth interview. Variables are mother's knowledge, family support and motivation from health staff toward the succes of ESI implementation. The data were analyzed with content analysis.

The results of this study showed that ESI hasn't been implemented well yet and the implementation of ESI hasn't succeeded yet. Mother's knowledge about ESI are still low, so that the mother didn't have

Alamat Korespondensi: Novita Rany, STIKes Hang Tuah Pekanbaru Prodi IKM, Jalan Mustafa Sari No 5 Tangkerang Selatan Pekanbaru Riau, Hp : 081268552844, email : novitarany@ rocketmail.com 
motivation to do ESI untill succeed. The lack of information about ESI from member of the family also affecting mother's motivation to do ESI. Motivation of health staff still low. The health staff never give information about ESI to the mother and implementation of ESI only 15 minutes. It is suggested for midwives in Taman Sari Clinical Center to increase mother's knowledge about ESI and to give information about ESI through the posters.

Key words : Implementation of ESI, the success of ESI implementation, mother's knowledge, motivation of family member, motivation of health staff.

\section{Pendahuluan}

Air Susu Ibu (ASI) merupakan makanan yang terbaik untuk bayi, namun pemberian ASI terutama ASI eksklusif masih rendah. Menurut Survei Demografi Kesehatan Indonesia (SDKI) terjadi penurunan pemberian ASI eksklusif yaitu dari 7,9\% pada tahun 1997 menjadi 7,8\% pada tahun 2002. Hasil SDKI tahun 2007 menunjukkan jumlah bayi yang mendapatkan ASI eksklusif hanya 7,2\%. Sementara pemberian susu formula terus meningkat, yaitu dari $16,7 \%$ pada tahun 2002 menjadi 27,9\% pada tahun 2007. Hal ini tentu saja sangat memprihatinkan, mengingat ASI memiliki banyak keunggulan dibanding susu formula.

Inisiasi Menyusu Dini (IMD) merupakan salah satu upaya untuk meningkatkan cakupan ASI eksklusif. Berdasarkan hasil penelitian Fikawati dan Syafiq (2003) yang dikutip dari Roesli (2008), bayi yang berkesempatan melakukan IMD pada usia enam bulan sebesar 59\% masih menyusu dan bayi usia 12 bulan sebesar $38 \%$ masih menyusu. Pada bayi yang tidak diberi kesempatan IMD, pada usia enam bulan hanya $19 \%$ yang masih menyusu dan untuk bayi berusia 12 bulan hanya $8 \%$ yang masih menyusu. Bayi yang diberi kesempatan menyusu dini akan delapan kali lebih berhasil dalam menyusu eksklusif. Berarti, bayi yang diberi kesempatan IMD akan lebih mungkin disusui sampai usia dua tahun, bahkan lebih.

Penelitian Edmond (2006) di Ghana, menunjukkan bahwa IMD berperan dalam pencapaian tujuan Millennium Development Goals (MDGs) yaitu jika bayi diberi kesempatan melakukan IMD maka $22 \%$ nyawa bayi di bawah 28 hari dapat diselamatkan.

Penelitian menunjukkan bahwa IMD ternyata berpengaruh terhadap pertumbuhan selanjutnya. Lambatnya IMD ternyata menghambat pertambahan berat badan bayi karena memberi peluang pemberian makanan/minuman selain ASI (Soekirman et al, 2006). Menurut penelitian Lepong dan Ngadiarti (2009) di Jakarta Timur ibu yang melaksanakan IMD hanya $31,96 \%$. Pertumbuhan berat badan bayi yang mendapatkan IMD lebih besar dari pada yang tidak mendapatkan IMD.

Berdasarkan hasil survei pemberian ASI Eksklusif di wilayah kerja Dinas Kesehatan Provinsi Riau tahun 2008, dari 133,596 bayi yang didata, hanya sekitar 48,813 atau $36,5 \%$ saja yang memberikan ASI Eksklusif. Selanjutnya data dari Dinas Kesehatan Kota Pekanbaru tahun 2008, dari 20,862 bayi yang didata, hanya 3,764 atau $18,04 \%$ saja yang memberikan ASI Eksklusif.

Belum ada data konkrit tentang pelaksanaan IMD di wilayah kerja Dinas Kesehatan Kota Pekanbaru. Hasil survei yang dilakukan oleh peneliti di beberapa rumah bersalin di Pekanbaru, Rumah Bersalin Taman Sari merupakan rumah bersalin yang sudah melaksanakan program Inisiasi Menyusu Dini (IMD).

Berdasarkan data dari Rumah Bersalin (RB) dan Balai Pengobatan (BP) Taman Sari Pekanbaru Tahun 2009, dari 378 Ibu yang melahirkan secara normal yang sudah melakukan IMD sekitar $80 \%$. Hal ini menunjukkan bahwa pelaksanaan IMD di Rumah Bersalin dan Balai Pengobatan 
Taman Sari sudah terlaksana. Namun dari hasil wawancara awal yang telah dilakukan kepada tiga orang ibu masa nifas yang melahirkan secara normal dan telah melaksanakan IMD di Rumah Bersalin dan Balai Pengobatan Taman Sari Pekanbaru, didapat data bahwa tidak ada ibu yang berhasil melakukan IMD, karena bayi tidak berhasil menghisap puting susu ibu.

Banyak faktor yang dapat mempengaruhi keberhasilan pelaksanaan IMD diantaranya pengetahuan ibu, motivasi keluarga dan motivasi petugas dalam pelaksanaan IMD. Berdasarkan latar belakang di atas peneliti berminat untuk melakukan penelitian yang lebih dalam tentang "Analisis keberhasilan pelaksanaan Inisiasi Menyusu Dini (IMD) di Rumah Bersalin dan Balai Pengobatan Taman Sari Pekanbaru".

Tujuan Umum : Mengetahui keberhasilan pelaksanaan IMD di Rumah Bersalin dan Balai Pengobatan Taman Sari Pekanbaru Tahun 2010. Tujuan Khusus : a. Menganalisis pelaksanaan IMD; b. Menganalisis keberhasilan pelaksanaan IMD; c. Menganalisis pengetahuan ibu tentang IMD; d. Menganalisis motivasi keluarga dalam pelaksanaan IMD; e. Menganalisis motivasi petugas dalam pelaksanaan IMD.

\section{Metode}

Penelitian ini menggunakan jenis penelitian kualitatif yang bertujuan untuk mengetahui pelaksanaan IMD, keberhasilan pelaksanaan IMD, pengetahuan ibu tentang IMD, motivasi keluarga dan motivasi petugas dalam pelaksanaan IMD di RB dan BP Taman Sari Pekanbaru tahun 2010.

Penelitian dilaksanakan di RB dan BP Taman Sari Pekanbaru tahun 2010 selama bulan Januari-April 2010. Subjek utama dalam penelitian ini adalah ibu yang melahirkan secara normal dan telah melaksanakan IMD. Subjek pendukung adalah anggota keluarga ibu dan bidan di RB dan BP Taman Sari Pekanbaru Tahun
2010. Jumlah Informan pada penelitian ini berjumlah sepuluh orang yang terdiri dari empat orang ibu yang melahirkan secara normal dan telah melaksanakan IMD, empat orang anggota keluarga ibu, dan dua orang bidan di RB dan BP Taman Sari Pekanbaru.

Kriteria Informan adalah 1) ibu melahirkan di RB dan BP Taman Sari pekanbaru, selamat dalam proses persalinan, melahirkan secara normal, tidak melahirkan dengan obat-obatan perangsang, melahirkan bayi yang memenuhi kriteria untuk menjadi informan dalam penelitian ini, melaksanakan IMD 2) Bayi lahir cukup bulan, tidak cacat, dilahirkan oleh ibu yang memenuhi kriteria 3) Anggota keluarga ibu yang mendampingi ibu saat memeriksakan kehamilan dan saat persalinan 4) Bidan yang bertugas di RB dan BP Taman Sari Pekanbaru, memeriksa kehamilan dan membantu persalinan ibu yang menjadi responden.

Variabel penelitian adalah pengetahuan ibu, motivasi keluarga, motivasi petugas, pelaksanaan IMD, keberhasilan pelaksanaan IMD. Instrumen Penelitian terdiri dari pedoman wawancara, pedoman observasi, alat pencatat, alat perekam berupa tape recorder, alat pengukur waktu berupa jam serta kamera digital.

Pengolahan data dilakukan dengan membuat transkrip data hasil wawancara mendalam dan membuat narasi hasil observasi. Data dianalisis dengan menggunakan analisis isi (content analysis).

\section{Hasil}

\section{Pelaksanaan IMD}

Hasil observasi pada ke-4 ibu saat persalinan didapat bahwa saat bayi lahir yang dilakukan bidan adalah memotong tali pusat bayi, mengeringkan seluruh badan bayi tanpa terkecuali dengan menggunakan kain bedung diatas perut ibu, dan bayi diletakkan diatas dada ibu kontak antara kulit dan kulit, bayi menggunakan topi dan diselimuti serta 
bayi dalam keadaan ada yang mengemut jari, ada yang membuka mulut, dan ada yang dalam keadaan menangis. Saat bayi diatas dada ibu bidan sibuk menjahit perinium, ibu hanya memegang bayi tanpa memberi rangsangan apapun dan keluarga ibu hanya diam melihat. Berdasarkan hasil observasi didapat bahwa pelaksanaan IMD pada bayi 1 berlangsung 15 menit, pada bayi ke 2 berlangsung 15 menit, pada bayi ke 3 berlangsung 15 menit dan pada bayi ke 4 berlangsung 10 menit. Semua bayi dalam waktu tersebut masih dalam keadaan siaga/diam.

Berdasarkan hasil observasi saat pelaksanaan IMD diketahui bahwa tidak ada satu pun bayi yang berhasil menemukan dan menghisap puting susu ibunya. Setelah 15 menit bidan mengangkat bayi, ditimbang, disuntik, diberi salep mata, dan dibedung tanpa dikembalikan ke dada ibunya dan akhirnya bayi diberi susu formula. Untuk itu dapat diketahui bahwa pelaksanaan IMD tidak berhasil.

\section{Pengetahuan Ibu}

Berdasarkan hasil wawancara mendalam kepada ibu yang melahirkan secara normal dan telah melaksanakan IMD di RB dan BP Taman Sari Pekanbaru Tahun 2010, diketahui bahwa dua informan menyatakan pernah mendengar IMD dan dua informan lagi tidak mengetahui apa itu IMD, seperti pernyataan mereka berikut.

" pernah denger sih.." (R1)
"ndak.." (R2)

Informan pernah mendengar IMD dari televisi dan adiknya.

$$
\text { "mmm..dari adek saya" (R1) }
$$

Dua orang informan mempunyai pengetahuan tentang IMD. Berikut kutipan wawancaranya:

"gimana ya.. jelasinnya.., anak saya diletakkan di dada saya, itu ya dek maksudnya?' (R1)
Seluruh responden sudah mengetahui minuman yang terbaik untuk bayi yaitu ASI.

$$
\text { "Ya, ASI" (R1) }
$$$$
\text { "ASI" (R2) }
$$

Pada umumnya responden belum mengetahui dengan pasti manfaat dari IMD, namun ada dua informan yang sudah mengetahui manfaat dari IMD.

"Itu ya, biar dia bisa ini ya cari..apa namanya..puting susu" (R1)

"Bagus" (R2)

\section{Motivasi keluarga}

Pada saat pelaksanaan IMD ibu didampingi oleh keluarga seperti suami dan kakak kandung. Dari hasil observasi diketahui bahwa keluarga ibu yang mendampingi ibu saat persalinan tidak ada satu pun yang memberi motivasi saat pelaksanaan IMD. Mereka hanya diam melihat tanpa melakukan tindakan apapun. Oleh karena itu dapat diketahui bahwa motivasi keluarga dalam pelaksanaan IMD masih rendah.

Berdasarkan hasil wawancara mendalam kepada keluarga ibu yang telah mendampingi ibu saat pelaksanaan IMD di Rumah Bersalin dan Balai Pengobatan Taman Sari Pekanbaru, diketahui bahwa seluruh informan belum mengetahui apa itu IMD.

\footnotetext{
"Gak tau lah itu.." (I)

"Gak tau" (II)

"Gak tau" (III)
}

Pada umumnya informan pernah menyarankan ibu untuk membiarkan bayi segera menyusu di atas dada ibu dalam satu jam setelah lahir.

$$
\begin{aligned}
& \text { "O...pernah..." (I) } \\
& \text { "Mmm...pernah" (II) } \\
& \text { "O... itu sering.." (III) } \\
& \text { "Gak pernah.., ya karna saya belum } \\
& \text { tau" (IV) }
\end{aligned}
$$

Informan yang sudah memberikan saran kepada ibu, menyatakan bahwa tanggapan 
ibu senang dan menerima saran yang diberikan.

$$
\begin{aligned}
& \text { "senenglah dia..biar tau dia.." (I) } \\
& \text { "baguslah....katanya" (II) } \\
& \text { "ya...gak apa-apa bagus aja } \\
& \text { katanya" (III) }
\end{aligned}
$$

Seluruh responden menyatakan memberi dukungan kepada ibu saat pelaksanaan IMD.

$$
\begin{aligned}
& \text { "ya, memberi dukungan" (I) } \\
& \text { "Semangatkan aja.." (II) } \\
& \text { "iya" (III) } \\
& \text { "ya, memberi dukungan lah..." (IV) }
\end{aligned}
$$

\section{Motivasi petugas (Bidan)}

Hasil observasi saat pelaksanaan IMD diketahui bahwa bidan sudah melaksanakan tahap-tahap IMD namun belum mengarahkan dan membimbing ibu dalam pelaksanaan IMD yang benar, hal ini dapat dilihat dari cara bidan mengeringkan bayi, bidan mengeringkan badan bayi tanpa terkecuali (termasuk kedua tangan bayi dan cairan verniks dikeringkan) dan pelaksanaan IMD hanya berlangsung 15 menit. Oleh karena itu dapat diketahui bahwa motivasi petugas masih rendah.

\section{Pembahasan}

\section{Pelaksanaan IMD}

Berdasarkan hasil observasi diketahui bahwa bidan sudah mengikuti tahap-tahap pelaksanaan IMD seperti memotong tali pusat bayi, mengeringkan bayi, meletakkan bayi di atas dada ibunya dengan kontak kulit dan kulit, bayi diberi topi dan diselimuti. Namun cara bidan dalam mengeringkan bayi belum benar, karena seluruh badan bayi dikeringkan tanpa terkecuali, sebaiknya cara mengeringkan yang benar yaitu tubuh bayi dikeringkan kecuali kedua tangannya karena bau ditangan bayi menyerupai bau ASI sehingga menuntun bayi untuk menemukan puting susu ibunya dan verniks atau lemak putih yang menempel di kulit bayi seharusnya tidak dibersihkan karena zat ini menyamankan kulit bayi.
Menurut JNPK-KR (2007), dalam mengeringkan tubuh bayi, hindari mengeringkan tangan bayi. Bau cairan amnion pada tangan bayi juga membantunya mencari puting susu ibunya yang berbau sama. Roesli (2008) juga mengatakan verniks (zat lemak putih) yang melekat di tubuh bayi sebaiknya tidak dibersihkan karena zat ini membuat nyaman kulit bayi.

Berdasarkan hasil pengamatan peneliti pelaksanaan IMD hanya berlangsung ratarata 15 menit saja. Sebaiknya pelaksanaan IMD dilakukan sekurang-kurangnya selama 1 jam, karena menurut JNPK-KR (2007), biarkan bayi tetap melakukan kontak kulit ke kulit di dada ibu paling sedikit satu jam. Sebagian besar bayi akan berhasil melakukan Inisiasi Menyusu Dini dalam waktu 30-60 menit. Roesli (2008) juga mengemukakan dalam waktu 15-30 menit bayi masih dalam stadium istirahat/diam dalam keadaan siaga.

Saat observasi terlihat rata-rata bayi dalam keadaan membuka mulut. Hal ini menandakan bayi siap untuk mencari dan minum ASI ibunya, namun sayang bayi tidak diberi kesempatan untuk melakukan semua itu, padahal bayi sudah menunjukkan perilaku alaminya untuk mendapatkan sumber kehidupannya yaitu ASI.

Berdasarkan teori dan penelitian tersebut dapat disimpulkan bahwa bayi belum dapat menemukan dan menghisap puting susu ibunya hanya dalam waktu 15 menit.

\section{Keberhasilan Pelaksanaan IMD}

Berdasarkan hasil observasi dapat diketahui bahwa tidak ada satu pun ibu yang berhasil melaksanakan IMD. Hanya dalam waktu 15 menit bayi tidak akan bisa menemukan dan menghisap puting susu ibunya, selanjutnya bidan tidak meletakkan kembali bayi di atas dada ibunya, bahkan selanjutnya bayi diberi susu formula. Padahal susu formula sangat tidak baik diberikan pada bayi. 
IMD dikatakan berhasil apabila bayi dapat menemukan dan menghisap puting susu ibunya dalam satu jam pertama kelahirannya, dan jika satu jam pertama bayi tidak berhasil maka dicoba lagi diletakkan di dada ibunya dengan kontak kulit dan kulit selama satu jam lagi. Menurut JNPK-KR (2007) jika bayi belum berhasil melakukan inisiasi menyusu dini dalam waktu satu jam, posisikan bayi lebih dekat dengan puting susu ibu dan biarkan kontak kulit dengan selama 30-60 menit berikutnya.

Hasil penelitian Edmond (2006) yang dilakukan di Ghana terhadap 11.000 bayi, didapat bahwa jika bayi berhasil melakukan IMD dalam satu jam pertama dengan dibiarkan kontak kulit ke kulit ibu (setidaknya selama satu jam) maka $22 \%$ nyawa bayi di bawah 28 hari dapat diselamatkan.

Hasil observasi menunjukkan saat pelaksanaan IMD tidak berhasil bidan langsung mengangkat bayi untuk mendapatkan asuhan bayi baru lahir dan kemudian dibedung tanpa diletakkan kembali kontak kulit dan kulit di atas dada ibunya dan diberi susu formula.

Menurut Roesli (2008) makanan awal nonASI mengandung zat putih telur yang bukan berasal dari susu manusia, misalnya susu hewan. Hal ini dapat mengganggu pertumbuhan fungsi usus dan mencetuskan alergi lebih awal.

\section{Pengetahuan ibu}

Berdasarkan hasil observasi yang dilakukan peneliti saat pelaksanaan IMD berlangsung ibu tidak melakukan apa-apa, melainkan hanya memegang bayinya saja. Hal ini juga diperkuat dengan hasil wawancara mendalam dimana ibu menyatakan saat bayi di atas dada ibu, ibu hanya memegang bayi tanpa memberikan rangsangan apapun. Sebaiknya selama bayi di atas dada ibu, ibu memberikan rangsangan dengan membelai tubuh bayi dengan lembut, agar bayi merasa nyaman dekat dengan ibunya dan aktif untuk berusaha mencari puting susu ibunya.
Menurut JNPK-KR (2007) selama pelaksanaan IMD ibu dapat merangsang bayi dengan memeluk dan membelai bayinya.

Ibu tidak melakukan hal tersebut dapat disebabkan karena ibu tidak mengetahui apa yang harus dilakukan saat pelaksanaan IMD berlangsung. Hal ini disebabkan juga karena ibu kurang mendapatkan informasi tentang IMD, sehingga pengetahuan ibu tentang IMD masih rendah dan tidak dapat untuk menerapkan pada tindakan nyatanya. Roesli (2008) juga mengemukakan bahwa informasi yang diperoleh ibu tentang IMD juga mendukung dalam keberhasilan pelaksanaan Inisiasi Menyusu Dini.

Ibu pada dasarnya tidak pernah memperoleh informasi tentang IMD dari petugas RB dan BP Taman Sari Pekanbaru, dua orang ibu yang menyatakan mengetahui tentang IMD hanya memperoleh informasi dari televisi dan orang terdekat. Hal ini mengakibatkan informasi yang di dapat tidak banyak dan bahkan masih ada ibu yang belum pernah mengetahui tentang IMD dan manfaat dari IMD.

\section{Motivasi keluarga}

Berdasarkan hasil observasi yang dilakukan peneliti pada 4 orang anggota keluarga ibu yang mendampingi ibu saat persalinan di RB dan BP Taman Sari diperoleh bahwa, selama pelaksanaan IMD berlangsung anggota keluarga ibu tidak ada yang memberi ibu dukungan atau motivasi.

Hal ini dapat diketahui dari pengamatan peneliti, selama pelaksanaan IMD berlangsung anggota keluarga ibu hanya diam melihat, tanpa melakukan apapun. Hal ini dapat disebabkan karena pengetahuan/informasi yang diperoleh anggota keluarga ibu masih sangat rendah, sehingga mengakibatkan motivasi keluarga dalam pelaksanaan IMD masih rendah.

Berdasarkan hasil wawancara mendalam yang dilakukan pada 4 orang anggota keluarga ibu antara lain: tiga 
orang suami dan satu orang kakak kandung ibu, diperoleh bahwa ke empat informan belum mengetahui IMD, namun dari empat informan, tiga diantaranya mengaku pernah menyarankan ibu untuk meletakkan bayi di dada ibu satu jam pertama setelah lahir, sedangkan satu informan lagi menyatakan tidak pernah menyarankan ibu dengan alasan tidak pernah mengetahui tentang IMD.

Berdasarkan hasil wawancara mendalam, ke empat anggota keluarga ibu menyatakan mendukung ibu saat pelaksanaan IMD berlangsung, namun pada umumnya seluruh informan menyatakan cara mereka mendukung hanya dengan perasaan senang dan setuju tanpa ada tindakan nyata. Hal ini sesuai dengan hasil observasi yang dilakukan oleh peneliti bahwa anggota keluarga ibu tidak ada yang memberi dukungan yang nyata untuk meningkatkan percaya diri ibu selama pelaksanaan IMD berlangsung.

Menurut Roesli (2008) pada pelaksanaan inisiasi menyusu dini dianjurkan kepada ayah agar membantu ibu untuk mengenali tanda-tanda atau perilaku bayi sebelum menyusu. Dukungan ayah akan meningkatkan rasa percaya diri ibu.

\section{Motivasi petugas}

Observasi yang dilakukan pada saat bidan RB dan BP Taman Sari menolong persalinan diperoleh bahwa tahap-tahap bidan dalam pelaksanaan IMD adalah bayi lahir langsung dilakukan pemotongan tali pusat, bayi dikeringkan di atas perut ibu yang di alasi kain kering, seluruh badan bayi dikeringkan tanpa terkecuali. Selanjutnya bayi diletakkan oleh bidan di atas dada ibu tanpa dialasi kain yaitu kontak kulit bayi dan kulit ibu, bayi di beri topi dan di selimuti. Selama bayi di atas dada ibu bidan sibuk menjahit perinium, dan IMD hanya berlangsung 15 menit saja. Kemudian bayi diangkat, dibersihkan, disuntik, diberi salep mata, ditimbang lalu di bedung dan diberi susu formula.
Pelaksanaan IMD oleh bidan tidak sesuai dengan tatalaksana IMD yang baik dan benar. Hal ini dapat dilihat dari cara mengeringkan bayi, seharusnya bayi dikeringkan kecuali kedua tangannya karena cairan yang ada di tangan bayi mempunyai bau dan rasa yang sama dengan ASI. Hal ini akan menuntunnya untuk menemukan puting susu ibu. Begitu juga dengan verniks (zat lemak putih) yang menempel pada bayi sebaiknya jangan di bersihkan karena zat itu menyamankan kulit bayi.

Hal tersebut diperkuat dengan teori menurut Roesli (2008) kedua tangan bayi tidak boleh dikeringkan karena cairan ditangan bayi menyerupai bau ASI sehingga menuntun bayi untuk mencari puting susu ibunya serta vernix (lemak putih) sebaiknya tidak dibersihkan karena zat ini membuat nyaman kulit bayi.

Selain itu bidan juga tidak melaksanakan prinsip IMD. Hal ini dibuktikan dengan pelaksanaan IMD hanya berlangsung 15 menit. Menurut tatalaksana IMD yang benar, pelaksanaan IMD itu berlangsung sekurang-kurangya 1 jam, karena pada umumya bayi berhasil menemukan dan menghisap puting susu ibu pada usia 60 menit, pada usia 15 menit bayi masih dalam stadium istirahat keadaaan siaga.

Menurut JNPK-KR (2007), biarkan bayi tetap melakukan kontak kulit ke kulit di dada ibu paling sedikit satu jam. Sebagian besar bayi akan berhasil melakukan IMD dalam waktu 30-60 menit. Dengan waktu 30-60 menit ini kontak kulit antara bayi dan ibu akan mencegah kejadian hipotermi pada bayi baru lahir.

Berdasarkan hasil observasi di atas dapat disimpulkan bahwa bidan belum mengarahkan dan membimbing dalam pelaksanaan IMD yang benar. Hal ini dapat sebabkan karena bidan ingin cepat selesai sehingga pelaksanaan IMD yang dilakukan hanya sebagai syarat tanpa melakukan tahap-tahap yang benar dan tepat, sehingga akibatnya pelaksanaan IMD pun tidak berhasil dilakukan. 


\section{Kesimpulan Dan Saran}

Pelaksanaan IMD di RB dan BP Taman Sari Pekanbaru belum terlaksana dengan baik dan benar. Hal ini dapat disebabkan karena masih rendahnya motivasi dari petugas dan keluarga dalam pelaksanaan IMD serta masih kurangnya pengetahuan ibu tentang IMD.

Saran Bagi bidan RB dan BP Taman Sari Pekanbaru perlu memberikan motivasi untuk keberhasilan pelaksanaan IMD dengan cara memberikan informasi tentang IMD kepada ibu yang memeriksakan kehamilannya beserta anggota keluarganya dan mengarahkan tahap-tahap pelaksanaan IMD yang benar, memasang poster-poster tentang IMD, dan pelatihan-pelatihan untuk petugas penolong persalinan.

\section{Ucapan Terima Kasih}

Ucapan terima kasih kami sampaikan kepada Direktur Rumah Bersalin dan Balai Pengobatan Taman Sari Pekanbaru, bidan, dan responden, serta semua pihak yang telah membantu penelitian ini.

\section{Daftar Pustaka}

Budiasih, S, K. 2008. Handbook ibu menyusui. PT. Karya kita. Bandung.

Edmond, M, K. 2006. Delayed breastfeeding initiation increases risk of neonatal mortality. Pediatric.

Jaringan Nasional Pelatihan KlinikKesehatan Reproduksi (JNPK-KR). 2007. Pelatihan asuhan persalinan normal bahan tambahan inisiasi menyusu dini. Jakarta.

Lepong, M.P., and Ngadiarti, I. 2009. The influence of early suckling initiation to the growth and health of 2 months infants in east Jakarta. The emerging of double burden, nutrition problem in Indonesia. International Dietetic Update., Yogyakarta.

Notoatmodjo, S. 2005. Promosi kesehatan teori dan aplikasi. Rineka Cipta. Jakarta.

Roesli, U. 2008. Inisiasi Menyusu Dini plus ASI eksklusif. Pustaka Bunda. Jakarta.

Soekirman \& Susana, H. (Eds). 2006. Hidup sehat. PT. Primamedia Pustaka. Jakarta.

Survei Demografi kesehatan Indonesia (SDKI). 1997.

Survei Demografi kesehatan Indonesia (SDKI). 2002.

Survei Demografi kesehatan Indonesia (SDKI). 2007 